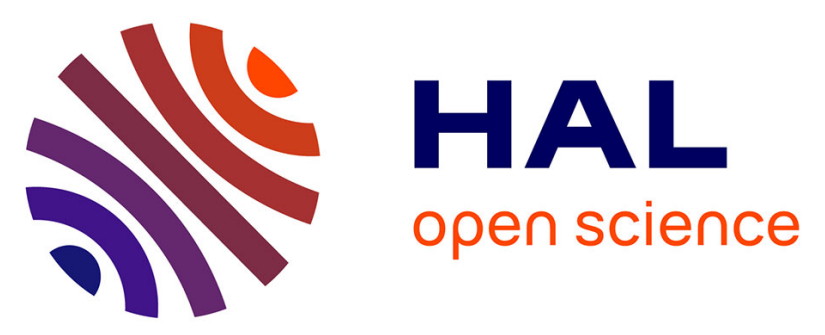

\title{
Comment on "The Chongón/Colonche orocline transrotational bending and the coeval opening of the Progreso basin in southwestern Ecuador" by Alemán et al
}

Carlos Aizprua, Cesar Witt, Jean-Yves Reynaud, Marc Poujol, Diego Barba

\section{To cite this version:}

Carlos Aizprua, Cesar Witt, Jean-Yves Reynaud, Marc Poujol, Diego Barba. Comment on "The Chongón/Colonche orocline transrotational bending and the coeval opening of the Progreso basin in southwestern Ecuador" by Alemán et al. Journal of South American Earth Sciences, 2022, pp.103714. 10.1016/j.jsames.2022.103714 . insu-03528819

\section{HAL Id: insu-03528819 \\ https://hal-insu.archives-ouvertes.fr/insu-03528819}

Submitted on 17 Jan 2022

HAL is a multi-disciplinary open access archive for the deposit and dissemination of scientific research documents, whether they are published or not. The documents may come from teaching and research institutions in France or abroad, or from public or private research centers.
L'archive ouverte pluridisciplinaire HAL, est destinée au dépôt et à la diffusion de documents scientifiques de niveau recherche, publiés ou non, émanant des établissements d'enseignement et de recherche français ou étrangers, des laboratoires publics ou privés. 


\title{
Comment on "The Chongón/Colonche orocline transrotational bending and the coeval opening of the Progreso basin in southwestern Ecuador" by Alemán et al
}

\author{
Carlos Aizprua $^{\mathrm{a}, \mathrm{b}, *, 1}$, Cesar Witt ${ }^{\mathrm{b}}$, Jean-Yves Reynaud ${ }^{\mathrm{b}}$, Marc Poujol ${ }^{\mathrm{c}}$, Diego Barba ${ }^{\mathrm{d}}$ \\ ${ }^{a}$ Department of Geoscience and Petroleum, Norwegian University of Science and Technology (NTNU), S.P. Andersens veg 15a, 7491, Trondheim, Norway \\ ${ }^{\mathrm{b}}$ Univ. Lille, CNRS, Univ. Littoral Côte d'Opale, UMR 8187, LOG, Laboratoire d'Océanologie et de Géosciences, F 59000, Lille, France \\ ${ }^{\mathrm{c}}$ Univ. Rennes, CNRS, Géosciences Rennes - UMR 6118, F-35000, Rennes, France \\ ${ }^{\mathrm{d}}$ EP Petroecuador, Av. Naciones Unidas E-7-95 y Av. De Los Shyris, Quito, Ecuador
}

\section{Introduction}

Alemán et al., [2021] propose a model for the evolution of the Progreso Basin, located at the southernmost Northern Andes, based on the assumption of a counterclockwise rotation of the "Chongon/Colonghe orocline". At first glance, the geometrical-based model seems a reasonable solution, however, their interpretation leans on some weak assumptions and the existence of a poorly constrained paleo-suture. This led them to infer a $\sim 30^{\circ}$ counterclockwise block rotation, without presenting any structural or paleomagnetic evidence. In our opinion, Alemán et al., [2021] not only present a poorly data constrained model, but they also present an approach oriented to obviate and invalidate previous work as a manner to reinforce their own. Thus, this comment is an opportunity to discuss several critical points, which have neither been satisfactorily explained nor adequately constrained by Alemán et al., [2021].

Despite the Progreso Basin being the main focus of their article, the authors address several geodynamic aspects that in our opinion require a thorough evaluation. Among those we found: (1) the disagreement with the Caribbean Large Igneous Province (CLIP) model, without presenting any compelling argument and furthermore overlooking updated studies; (2) their tardy middle to Late Eocene subduction initiation coeval with the emplacement of the Macuchi arc disregarding possible flat-slab subduction periods and overlooking the presence of intrusions of Paleocene age, which suggest a subduction system in place by the Paleocene; (3) the dubious suture between their "Cayo arc" and the Piñon Block based on a direct link to the higher frequency content of gravity and magnetic anomalies; (4) the development of a NW-SE elongated lithospheric flexure (tectonic framework for their Paleocene to Eocene foredeep basin) triggered by their proposed short-lived Late Paleocene collision; (5) the transpressional character of the Jubones fault and its role on the development of a N-NE vergence fold and thrust belt; (6) the use of chronological and petrographical data without presenting basic and necessary information about sample location, analytical methods, operability conditions, errors, etc.

Throughout this comment, we also use this opportunity to clarify some of the statements or assumptions made by Alemán et al., [2021] regarding our work in Aizprua et al., [2020] and Witt et al., [2019b]. Furthermore, we provide further elements that reinforce our model, which considers the Progreso Basin as a sensu stricto forearc basin (a neutral-accretionary type based on the classification by Noda [2016]). The development of the basin, based on our interpretation, is controlled by the interaction between the remnants of an accretionary wedge (Santa Elena High) and a sliver of the CLIP (Piñon Block), together with a process of tectonic escape of the Northern Andes. The latter controlling the southern widening of the basin at least since the middle Miocene.

\section{Accretion of oceanic terranes}

A recurrent discrepancy between researchers working with the geology of the Northern Andes is related to the number of oceanic plateaus and accretionary episodes that have taken place since the Late Cretaceous. In this context, Alemán et al., [2021] support the premise of two distinctive intra-oceanic arcs and two episodes of accretion by concurring with Jaillard et al., [1995]. However, Alemán et al., [2021] overlooked the model updates presented by the same authors in Van Melle et al., [2008] and Jaillard et al., [2009]. For instance, Van Melle et al., [2008] present a re-evaluation of the stratigraphy and geochemical data

\footnotetext{
* Corresponding author. Department of Geoscience and Petroleum, Norwegian University of Science and Technology (NTNU), S.P. Andersens veg 15a, 7491, Trondheim, Norway.

E-mail address: calun@equinor.com (C. Aizprua).

${ }^{1}$ Present address: Equinor ASA, Arkitekt Ebbells veg 10, 7053 Trondheim, Norway.
} 
to conclude that the Piñon block represents a crustal fragmentation of the CLIP with the San Lorenzo built-in arc before the collision. Similarly, Jaillard et al., [2009] present a scenario of successive accretions, which considers a single plateau with a single built-in arc (San Lorenzo, Naranjal, Rio Cala arc, from south to north respectively) originally oriented NW-SE and subject to block rotation and further crustal fragmentation during the collision. An alternative interpretation suggesting the remnant of a split intra-oceanic arc developed before or coincident with the collision (Rio Cala to the east and San Lorenzo to the west), has been recently proposed by Aizprua et al., [2020], which accounts for the basement-onlapping series from the Cayo formation (volcaniclastic material derived from the arc), possibly developed within an intra-oceanic arc basin.

Contrary to Alemán et al., [2021], we support the CLIP model based on the comprehensive amount of available studies employing geochemical [Lebrat et al., 1985; Reynaud et al., 1999; Hughes and Pilatasig, 2002; Kerr et al., 2002; Mamberti et al., 2003; Van Melle et al., 2008], radiometric [Kerr et al., 2002; Luzieux, 2007; Vallejo, 2007; Vallejo et al., 2009], and paleomagnetic data [Roperch et al., 1987; Luzieux et al., 2006; Luzieux, 2007]. However, Alemán et al., [2021] cast valid doubts on the CLIP interpretation and the single terrane hypothesis based on older ages (85-98 Ma U/Pb in zircons) reported by Macías [2018] for several granitoid rocks intruding the Piñon Formation in SW Ecuador. But we consider that a more complex plateau architecture does not preclude the existence of a single accretional episode. Recent radiometric and geochemical analyses for some of these granitoid rocks presented by Seyler et al., [2021] report ages between 87 and $89 \mathrm{Ma}$ and indicate geochemical affinities with the Las Orquídeas volcanic rocks located $30-40 \mathrm{~km}$ to the west. This suggests that the plutonic and volcanic events were coeval and may be linked to the same magmatic event. Seyler et al., [2021] suggest that the Pascuales felsic intrusives are associated with a process of partial melting of mafic-ultramafic cumulates, probably related to the initial stage of subduction leading to the San Lorenzo and Rio Cala arcs.

\section{Collision of the so-called "Cayo arc" and development of a NW-SE lithospheric flexure}

\subsection{Proto suture and foredeep basin}

Alemán et al., [2021] propose the development of a foredeep basin (hosting the Azúcar Formation and Ancón Group) controlled by a Late Paleocene collision of the "Cayo remnant arc" against the Andean margin, based on a model proposed by Jaillard et al., [1995]. However, we found an inconsistency in this proposal, as it is difficult to reconcile the current location of the proposed suture (Chongón-Jipijapa-Jama), $\sim 150 \mathrm{~km}$ west of the collision front with the Andean margin. This is a key element on their tectonic framework, which leads them to propose the strike-slip reactivation of a paleo suture as a driving mechanism responsible for 1) the anticlockwise transrotation of the "Chongon/Colonche orocline" and 2) the coeval transtensional opening of the Progreso Basin, according to Alemán et al., [2021].

In addition, we found confusing the use of the name Cayo arc, as the majority of authors refer to Cayo as the formation composed of volcaniclastic material derived from the San Lorenzo arc [Aizprua et al., 2020, and referenced therein]. With this clarification in mind, we may infer that Alemán et al., [2021] refer to a new collisional and suturing event between the San Lorenzo arc and the Piñon Block. It is noteworthy that there are no direct constraints in the literature (even in Alemán et al., [2021]) supporting a Paleocene accretion of the San Lorenzo arc along the proposed Chongón-Jipijapa-Jama suture. According to Alemán et al., [2021], this process led to a westward vergence thrust stack that cause a NW-SE lithospheric flexure that hosted the Azúcar and Ancón flysh sequences, coincidentally only to the south of the Chongón Colonche Hills (CCH).

We found problematic the proposal of a lithospheric flexure and the foredeep basin hosting the Azúcar and Ancón flysh sequences driven by a short-lived Late Paleocene collisional event. In this regard, Alemán et al., [2021] do not present any constraint supporting a short-lived collision able to maintain a lithospheric flexure during at least $12 \mathrm{Ma}$ (the period between the sedimentation of the Azúcar Formation and Ancón Group; 60-48 Ma, without considering the Punta Ancon Formation; Witt et al., [2019b]). In our opinion, the flexure is most likely generated by a northeast-dipping subduction system in place at least since the Early Paleocene as proposed by Jaillard et al., [2009] and Aizprua et al., [2019] in their successive accretionary models.

Contrary to Alemán et al., [2021], we do not fully associate the shallow sourced gravity and magnetic anomalies to a suture, instead, we use it to outline shallow basement areas. An interpretation that led Aizprua et al., [2020] to outline the presence of an outer forearc high, which is defined as well by seismic profiles. Similar potential field anomalies along forearc regions, associated with the development of an outer forearc high, are for instance described in Alaska [the Border Range Fault system, Mankhemthong et al., 2013]; California [Great Valley Forearc basin, Godfrey et al., 1997]; and Central America [Sandino Basin, Andjić et al., 2018].

\subsection{Timing of subduction initiation}

Alemán et al., [2021] associate the timing of subduction initiation with the emplacement of the Macuchi volcanic arc during the Middle Eocene, based on a whole-rock K/Ar radiometric age of $41.6 \pm 2.1 \mathrm{Ma}$ for a basaltic andesite sample [Egüez, 1986], later confirmed by a more reliable ${ }^{40} \mathrm{Ar} /{ }^{39} \mathrm{Ar}$ age of $42.62 \pm 1.3 \mathrm{Ma}$ from a plagioclase of an andesite lava flow [Vallejo et al., 2009]. However, their correlation of the timing of subduction initiation is limited to the presence of magmatism, without considering the well-known occurrence of long-term arc gaps in subduction zones. A comprehensive list of different areas with identified gaps in arc magmatism, associated with decreasing slab angle and the absence of partial melting, is presented by McGeary et al., [1985]. Although several mechanisms have been proposed for the absence of arc volcanism above subducting plateaus [van Hunen et al., 2002]. Flat-slab subduction accompanied by an arc gap is well recognized along the Andes, such as the Peruvian flat-slab segment, just south of the Gulf of Guayaquil [Gutscher et al., 1999; Ramos and Folguera, 2009], thus past flat slab subduction can not be discarded.

Furthermore, detrital zircons obtained in SW Ecuador and NW Peru [Hessler and Fildani, 2015; Pepper et al., 2016; Witt et al., 2017; Witt et al., 2018; Witt et al., 2019a; Witt et al., 2019b; George et al., 2021] evidence several clusters of zircons of magmatic origin between 60 and 40 Ma. Schutte [2009] also acknowledge the existence of several magmatic bodies of early Paleogene age between 2 and $4^{\circ}$. The K/Ar ages (regionally corroborated by more robust U-Pb ages, Schutte et al., [2010]) in southern Ecuador plutons (i.e. San Lucas, Tampanchi, Catamayo, Rio Pichinal, and El Tingo) mapped in the 1:1M Ecuadorian geological map [Egüez et al., 2017] also attest to active magmatism from $62 \mathrm{Ma}$ to $50 \mathrm{Ma}$. A recent review of the magmatism in Ecuador since the collision and accretion of the CLIP presented by George et al., [2021], clearly highlights the presence of magmatism since $66 \mathrm{Ma}$.

The 65-45 Ma period in the detrital record in SW Ecuador (Santa Elena Peninsula and Progreso Basin) constrain a nearby magmatic arc whose zircon geochemistry define one of the most evolved periods in the Cenozoic magmatic history of this part of the Andes [Witt et al., 2021]. According to Alemán et al., [2021], since the collision of the CLIP at 75-65 Ma until their proposed Middle Eocene subduction initiation, the main geodynamic process controlling the tectonism of the region is linked to their dubious short-lived accretion of the "Cayo arc", discussed in the previous section. Aizprua et al., [2019] argue that the study area was subject to plate instability very likely associated with the northward migration of a triple plate junction, before the re-establishment of the margin in the Eocene. Farther north, in central and south Colombia the collision ended around 60-63 Ma, and the east-dipping subduction 
system restarted at $\sim 60-62$ Ma [Jaramillo et al., 2017; Zapata-Villada et al., 2021]. Jaramillo et al., [2017] attribute the 15 Ma period between collision at $\sim 75 \mathrm{Ma}$ and subduction restart at $60 \mathrm{Ma}$, to different stages of the collision up to a trench re-establishment, similar to the proposal of Aizprua et al., [2019]. Furthermore, ages of intrusions in the Central Cordillera in Colombia support an east-dipping subduction re-establishment since 60 Ma [Bayona et al., 2012; Jaramillo et al., 2017; Barbosa-Espitia et al., 2019] as proposed in Ecuador [Schutte, 2009; Vallejo et al., 2009]. In this regard, numerical modelling of oceanic plateaus accretion at continental margins shows that the re-establishment of a stable subduction may involves outward migration of the subduction zone, with the incoming oceanic crust underthrusting the fractured terrane, forming a new subduction zone behind the accreted terrane [Vogt and Gerya, 2014; Betts et al., 2015; Tao et al., 2020]. This result is of crucial importance in this region as it may partly explain the local development of some structural highs (e.g. the Santa Elena High) following the re-establishment of the new subduction zone. In addition, different authors based on field observations [Van Melle et al., 2008; Jaillard et al., 2009; Kennan and Pindell, 2009; Vallejo et al., 2019] and through tectonic reconstructions coupled with tomographically imaged mantle structure [Boschman et al., 2014; Braz et al., 2018] support the presence of an east-dipping subduction system since the Late Cretaceous, aspects clearly overlooked by Alemán et al., [2021].

On the other hand, we concur with Alemán et al., [2021] that several lines of evidence converge on the age of $43 \mathrm{Ma}$ as an important time in the geodynamic evolution of southern Ecuador and northern Peru. It represents one of the most important U-Pb clusters in detrital data [Witt et al., 2017; Witt et al., 2019b]. It is related to a major compression in northern Peru [Noble et al., 1997] and also related to intriguing zircon isotopic signatures resulting from a significant melt of mantle-wedge [Vallejo et al., 2016] or mantle melts near cratonic areas [Witt et al., 2021]. Finally, $43 \mathrm{Ma}$ is also roughly coeval with the onset of a sedimentary gap ( 40- $32 \mathrm{Ma}$; Witt et al., [2019b]) in SW Ecuador. The circa 43 Ma time is indeed key and may represent a period of significant changes in the evolution of the arc, however, we disagree with Alemán et al., [2021] that it represents the onset of the current eastward directed subduction system, as previously discussed. Finally, 1) an increase of velocity by $\sim 40 \mathrm{Ma}$ is not supported by a recent Andean kinematic model [Maloney et al., 2013], and 2) Alemán et al., [2021] do not provide any evidence for their "corollary" to link the $\sim 43$ Ma magmatic event (Macuchi arc) with the uplift of the Santa Elena Peninsula. Note also that the few published constraints for the $\sim 43$ Ma event [Vallejo et al., 2016; George et al., 2021], as well as new unpublished data [Witt et al., 2021], define the emplacement of the arc in an extensional setting; difficult to conciliate with an uplift in the forearc area.

\subsection{Depositional setting of the Azúcar Formation}

It seems to exist a misunderstanding by Alemán et al., [2021] when affirming that our interpretation of the Azúcar Formation is related only to the recording of an early trench-slope basin. This is the assertion presented by Benitez [1995] and Jaillard et al., [1995], cited in Aizprua et al., [2019] within the Geodynamic and Geological settings section. Herein, we present a unified tectonostratigraphic view of the Azúcar Formation for clarification, given the recurrent referral by Alemán et al., [2021] to the work presented by Aizprua et al., [2019] and Witt et al., [2019b].

Our analysis of surface exposures along the Estancia Hills and the Santa Elena Peninsula [Witt et al., 2019b] concur with previous ones [i. e. Luzieux, 2007] that the Azucar Formation was deposited by a coarse-grained, high energy turbiditic system likely source from a relief of Paleozoic and Triassic located to the south [Moreno, 1983; Benitez, 1995]. It was beyond our objectives in Witt et al., [2019b] to characterize in more detail the turbiditic system of the Azúcar Formation, maybe confusingly interpreted with a fan model such as that of Walker [1978]. We want to clarify that this model has neither direct implication on the geomorphic nor geodynamic setting of the hosting margin. As suggested by morphologic models such as those of Shanmugam and Moiola [1991] and Richards et al., [1998], channelized coarse-grained facies are expectedly more abundant in short and high-energy turbiditic systems which characterize active margins.

Unfortunately, there is no way to determine water depth from such turbiditic systems from the lithofacies only, so that this interpretation is not inconsistent with the occurrence of calcareous benthic foraminifers reported by Ordoñez et al., [2006], from what they concluded to a 2000-3000m water depth. Consistently with that intermediate, bathyal depth, the deposition of the Paleocene Azúcar Formation may have possibly occurred on top of the so-called "Santa Elena accretionary wedge" by Aizprua et al., [2019]. Still, this hypothesis is based on some observations across the Santa Elena Peninsula, where Paleogene sequences, attributed to the Azúcar Formation, unconformably overlie deformed series of the Santa Elena Fm. A proposal that certainly requires further data constraints.

Furthermore, a paleogeographic reconstruction of the proposed submarine slope at the time of deposition of the Azúcar Formation is impaired by the low-quality of the available 2D seismic profiles across this area, and by the degree of deformation. The extension of the deformed series of the Azúcar Formation can be followed across $100-150 \mathrm{~km}$, which suggest that the related turbiditic system was larger. The poor resolution of internal seismic geometries of Azúcar Formation does not preclude, however, that it was composed of smaller individual amalgamated mouth-lobe complexes, as suggested in the model of Shanmugam and Moiola [1991].

A tectonic process responsible for the development of a localized depocenter, hosting the Azúcar Formation, is proposed by Aizprua et al., [2019]. These authors consider that the area was controlled by the pre-collision geometry of the Andean margin, the collision and accretion of the trailing edge of an oceanic plateau, and thus the instability of a triple plate junction [Kennan and Pindell, 2009; Spikings et al., 2015; Aizprua et al., 2019]. These authors suggest that plate instability may have resulted in a tearing of the Piñon Block creating a localized depocenter, possibly NW of the Amotape-Tahuin massif (ATM). However, other terranes westward of the ATM share similar age affinities and might be good candidates for sourcing this depocenter [Witt et al., 2019b], a provenance model not considered by Alemán et al., [2021]. Therefore, a direct relationship between SW Ecuador sedimentation with the Amotapes as the main source, and the latest linked to an uplift of the El Oro Metamorphic Complex requires further work.

\subsection{N-NE vergence fold and thrust belt}

Alemán et al., [2021] also mention that the east directed stress (from their Paleocene collision event discussed previously) swerved rapidly to a N-NE stress triggered by the Jubones fault transpressional motion and the Amotape-Tahuin massif uplift. An event that led to the development of a N-NE vergence Fold and Thrust Belt (FTB). However, we find it hard to kinematically explain the coexistence of a NW-SE lithospheric flexure and the development of a N-NE vergence FTB by the shear stress along the Jubones fault. Moreover, the Jubones fault is associated with the southern suture of the CLIP, which has a near E-W orientation to the south of both the proposed NW-SE oriented flexure and the FTB (Fig. 1).

The N-S compressional event invoked by Alemán et al., [2021] leading to N-NE vergence FTB, is related to the $\mathrm{D}_{4}$ deformation event proposed by Riel et al., [2014], predominantly observed south of the El Oro Metamorphic Complex (south of the study area here in discussion). From the conclusions presented by Riel et al., [2014], we quote the following: "From the Campanian to Maastrichtian (80-65 Ma), extension switched to N-S directed compression, most probably related to the accretion of oceanic terranes both in Ecuador and Colombia". A statement strictly associated with the deformation styles observed southward at the Lancones Basin. This does not necessarily imply a FTB propagation from south to north as it seems the proposal by Alemán et al., [2021]. 

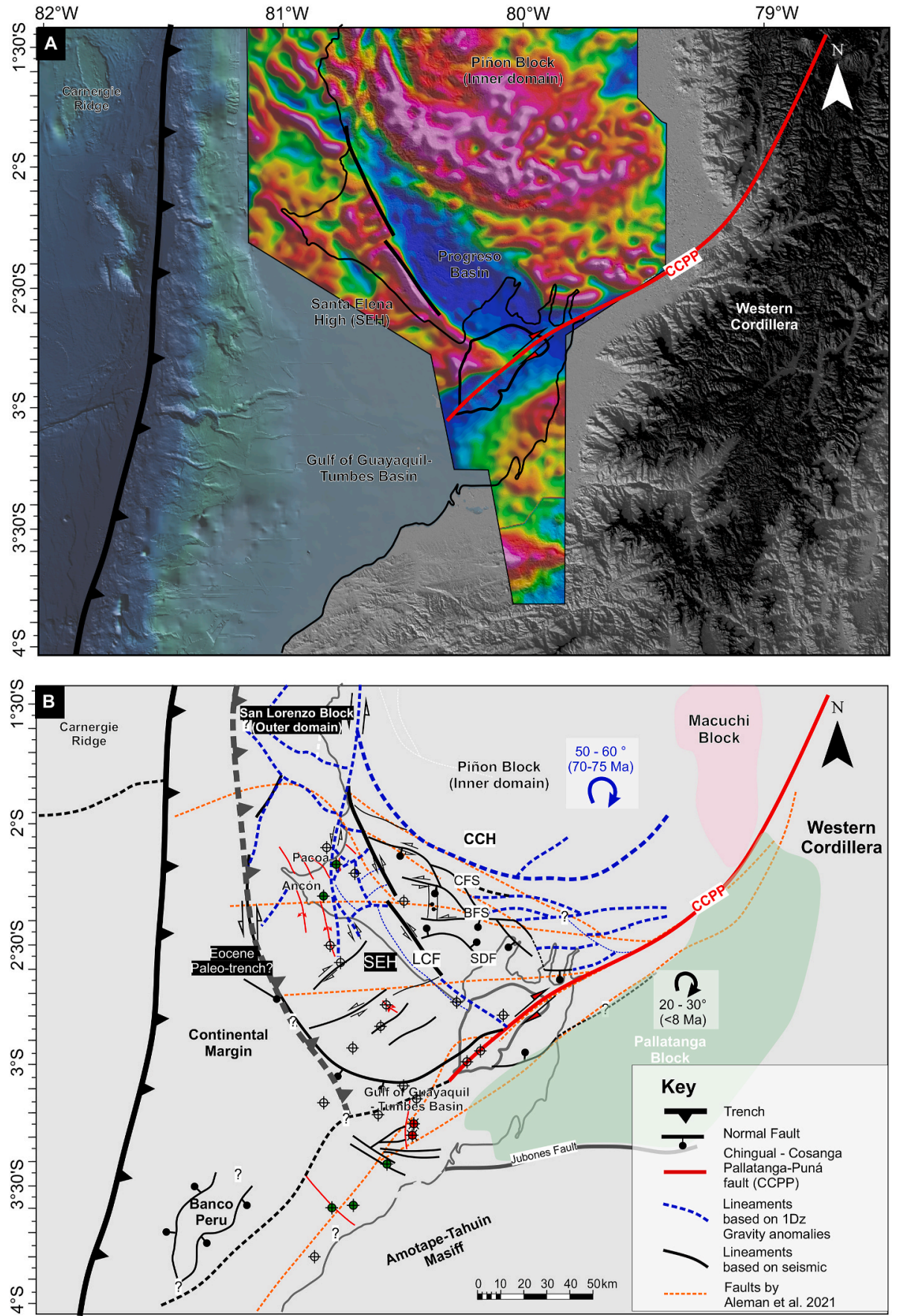

Fig. 1. A) Vertical derivative of the gravity anomaly map presented in Aizprua et al., [2019] across the onshore section of the Santa Elena High (SEH) and the Progreso Basin. B) Tectonic map of the major structural elements of the southernmost Northern Andes constrained to seismic, potential field, and surface data. Geophysical domains as defined by Aizprua et al., [2020]. BFS: Bajada Fault System; CCH: Chongon Colonche Hills; LCF: La Cruz Fault; SDF: Santo Domingo Fault.

The conclusion presented by Riel et al., [2014] is quite aligned with stages 1 and 2 (collision and margin instability) discussed in Aizprua et al., [2019]. We cannot completely discard that part of the N-S imposed compression may have affected the study area, particularly the southernmost area of the Santa Elena High (SEH). However, we concur with Riel et al., [2014] that the main driving mechanism in the deformation observed to the south is related to the process of accretion of an oceanic terrane since the Late Cretaceous.

In our opinion, the role of the Jubones fault, as considered in Alemán et al., [2021], in displacing Paleozoic rocks from the Eastern Cordillera towards the current location of El Oro Metamorphic Complex, and imposing a near N-S compression regime to SW Ecuador is highly unconstrained. The schematic section presented within the supplementary material (Figure S-1 in Alemán et al., [2021]) does not capture the complex tectonic setting between the Amotapes Massif and deformed depocenters located northwards (see for instance the cross-sections proposed by Espurt et al., [2018]). It is difficult to establish a direct relationship between the uplift of the Amotapes Massif and the structural and/or stratigraphic configuration of SW Ecuador. Furthermore, the main (?) uplift of the Amotapes Massif may have started around 40-25 Ma as expressed in thermal history models based on apatite fission-track (AFT) data [Spikings et al., 2005; Espurt et al., 2018]. For instance, the thermal models in Spikings et al., [2005] show a clear phase of cooling starting at 40 Ma north and south of the Jubones Fault 
at a rate of $\sim 5^{\circ} / \mathrm{Ma}$, whereas in Espurt et al., [2018] the main cooling phase for the Amotapes may have started at $\sim 25 \mathrm{Ma}$ at a similar rate, different to the one proposed by Alemán et al., [2021]. Both Spikings et al., [2005] and Espurt et al., [2018] do not show any conclusive result for the period between 70 and $40 \mathrm{Ma}$, these authors highlighted it by a question mark. Thus, these results do not support the continuous uplift of the Amotapes-Tahuin massif as suggested by Alemán et al., [2021].

Alemán et al., [2021] also suggest that seismic sections across the southernmost section of the SEH, presented in Aizprua et al., [2019], indicate a N-S vergence. An inferred direction that could be misleading based on single 2D seismic profiles. Fig. 2-A, shows a two-way-time-map of one of the main unconformities (Late Paleocene - Early Eocene) across the SEH, with a clear variety of fold axis directions.

The proto suture south of the SEH should be considered as well in any structural analysis as a plausible weak zone that may accommodate a large percentage of strain partitioning. According to kinematic models, which consider the coexistence of such major boundaries under oblique convergence, there is great variability between the main shortening direction (imposed by the subducting plate) and fold axis orientations [Teyssier et al., 1995]. A model that could explain the near NW fold vergence structures observed near this major boundary. As we mentioned previously, the deformation is most likely controlled by a NE dipping subduction system in place by early Paleocene, with a large strain partitioning across the SEH, contrary to the NW-SE lithospheric flexure proposed by Alemán et al., [2021].

Northwards, near the Ancón and Pacoa area (see Aizprua et al., [2019] for a more detailed description), Alemán et al., [2021] present a structural map (Fig. S-2) suggesting a variety of shortening directions. They conclude on a generalized N-S vergence by combining: 1) a map resulting from an over-interpreted seismic dataset, considering the low quality of the seismic profiles across this area (see seismic profiles presented by Aizprua et al., [2019]); and 2) a fault kinematic analysis along the Estancia Hills, which is an area very likely subject to a localized deformation, as we discuss in the next section. In our opinion, proposing a model based on the kinematic analysis along the Estancia Hills and associating it to an area bounded to the south and north by the westward extension of the suggested "Rodeo" and "Dorado" Riedels, respectively (Fig. 1-B), without presenting any regional constrain or strain partitioning considerations is misleading. Instead, we propose an integrated and more regional approach for the interpretation of this complex zone based on: gravity anomalies, available seismic data, and surface exposures (Fig. 1) [Aizprua et al., 2019; Witt et al., 2019b]. The resulting map shows a complex pattern, where the near $\mathrm{N}-\mathrm{S}$ vergence reverse faults could be linked to the development of a contractional duplex associated with a restraining bend or a process of northward block extrusion.

\section{Unconstrained counterclockwise rotation of the Chongon Colonche Orocline and opening of the Progreso Basin}

Alemán et al., [2021] recognize that their model relies on different geometrical observations that lead them to propose a counterclockwise block rotation of the so-called "Chongón Colonche orocline". However, these authors obviate discussing the available paleomagnetic data in the region, which are measurements that may have been useful to validate or disregard their transrotational model. Furthermore, Alemán et al., [2021] do not provide any detailed structural analysis or kinematic indicators, which together with paleomagnetic evidence are common
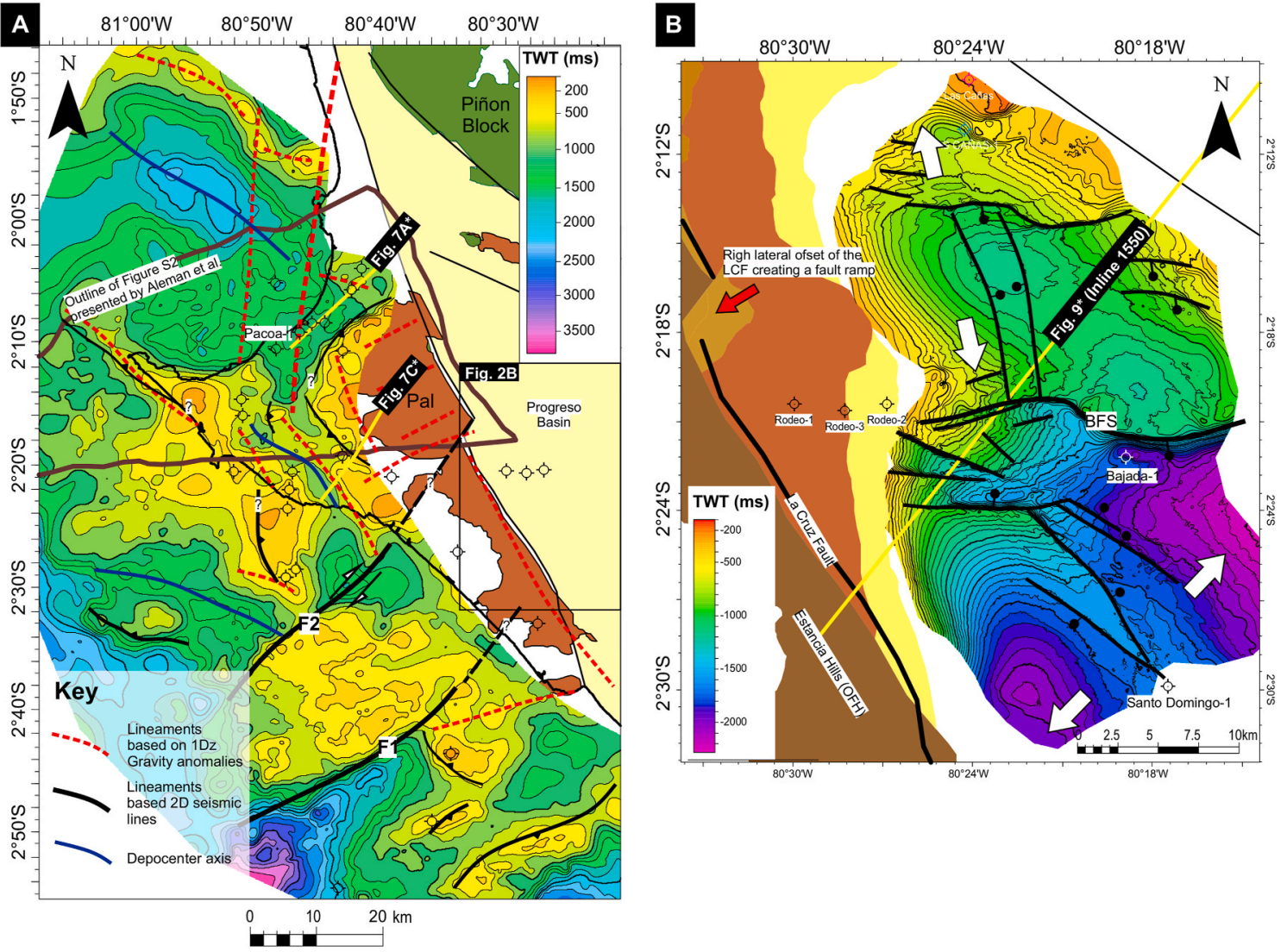

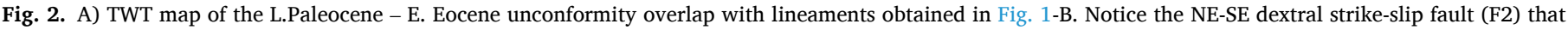

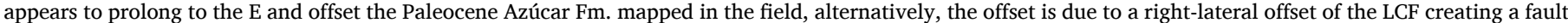

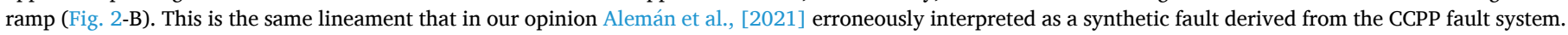

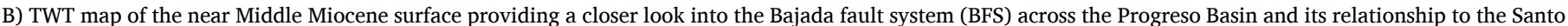
Domingo and Rodeo structures to the south and west respectively. (*indicates the location of the figures in Aizprua et al., [2019]). 
analyses when looking for block rotations across forearc slivers [e.g. Ron et al., 1984; Hernandez-Moreno et al., 2016]. The available paleomagnetic data, measured along the $\mathrm{CCH}$ and southward at the Amotape-Tahuin massif account for clockwise block rotations only. The existing data point towards a major clockwise block rotation during the Late Cretaceous for the $\mathrm{CCH}$, and a post Cretaceous (Oligocene?) clockwise rotation for the Amotape-Tahuin massif [Roperch et al., 1987; Mitouard et al., 1990; Luzieux et al., 2006]. Furthermore, a recent paleomagnetic study at the Western Cordillera may shade some light on plausible Cenozoic block rotations in the region, including the $\mathrm{CCH}$ [Siravo et al., 2021]. This latest study, together with a re-evaluation of the work from Luzieux et al., [2006], put in evidence a ca. 20-30 clockwise rotation towards the middle-late Miocene, invalidating the proposed counterclockwise rotation inferred by Alemán et al., [2021]. It is worth mentioning that there is no available paleomagnetic evidence in the literature supporting a counterclockwise rotation of the $\mathrm{CCH}$ or any of the surrounding blocks.

\section{Strain partitioning across the Progreso Basin and Santa Elena high}

\subsection{Santa Elena high}

It is known that the deformation imposed by oblique subduction is partitioned into trench parallel and normal components across the outer wedge and along zones of weakness such as a volcanic arc or a suture [Beck Jr., 1980; Woodcock, 1986; Dewey and Lamb, 1992; Wallace et al., 2004]. In the particular case of SW Ecuador and despite the contrasting models for the opening of the Progreso Basin, Alemán et al., [2021] and the authors of this comment agree primarily on two aspects 1) the pre-Oligocene existence of the Piñon Block's southern boundary, either called CCH or "Chongón/Colonche orocline", bounding the Santa Elena High to the SSW, and 2) a paleo-suture to the south, following the Jubones fault (?) (Fig. 1).

We interpret the Piñon Block's southern boundary as a lineament inherited from a possibly pre-existing NNE dipping subduction system, in place before the development of the Paleocene-Eocene outer wedge [Aizprua et al., 2019; Figure 14-A]. The resulting local geometry, following the re-establishment of a stable subduction system, might have been subject to a localized strain partitioning south of the $\mathrm{CCH}$.

A composed structural map indicating the main lineaments observed in the area based on seismic data (black) and a vertical derivative of the gravity anomaly (blue) are shown in Fig. 1-B. The strain partitioning across the SEH is evident by the existence of folded structures oriented NNW-SSE (red), with large variations near the La Cruz Fault [Alemán et al., 2021]; together with transtensional structures along the Carrizal Fault System (CFS), (Figs. 1 and 2).

Towards the complex onshore sector of the SEH, partly discussed in Aizprua et al., [2019]. We can observe a clear truncation of the gravity anomalies and an apparent displacement that suggest a sinistral movement around the western side of the Peninsula (near the Ancs.ón and Pacoa field, Fig. 1). This lineament together with the northern segment of the La Cruz fault may have controlled the possible development of a contractional duplex. A structure previously mapped by different authors [Benitez, 1995; Jaillard et al., 1997; Aizprua et al., 2019], however, without presenting any clear tectonic framework. Indeed, this structure shows a good correlation with the anomaly pattern of the gravity data and may explain the abrupt truncation of the Paleocene Azúcar Formation to the north. A series of stacked thrusts are observed to the NE (Pacoa area) and the west (Ancon field) of an area characterized by negative values on the vertical derivative, possibly outlining a principal deformation zone (PDZ). This tectonic model might explain better the differences in sedimentary facies and ages observed across this complex area. Indeed, Witt et al., [2019b] suggest considering a different formation for the deposits in the Pacoa area, based on the significant sedimentary differences and ages of deposit, unrelated to neither the Azúcar nor the Ancón Formations. The observations here presented may bring new insights into understanding the spatial and temporal relationship of these depocenters. It also shades light onto the understanding of possible hydrocarbon migration pathways, through such strike-slip fault system that interconnects these depocenters (i.e. Ancon and Pacoa fields). Contrary to an existing proposal, which consideres the existence of a riedel system (Rodeo riedel) connecting the deepest part of the Progreso Basin with the aforementioned depocenters across the SEH [Aguilar et al., 2009; Palencia et al., 2013]. A model which cannot be discarded, however, it requires further work.

\subsection{Progreso Basin}

We also have to disagree with the prolongation of the synthetic Riedel faults system proposed by Alemán et al., [2021] across the Progreso basin and through the Santa Elena High (Fig. 1-B). The vertical derivative of the gravity anomaly does not show clear evidence of large offset along the Estancia Hills to support a dextral movement for both the "Rodeo" and "Consuelo" Riedel systems (Fig. 1). Based on the integration of data of distinct scales, this interpretation is not fully supported and unfortunately, Alemán et al., [2021] do not present any persuasive evidence, beyond their schematic drawings.

A vertical derivative of the gravity anomaly map presented in Aizprua et al., [2020] across the Progreso basin supports a left lateral crustal movement at the southernmost segment of the basin. This is opposite to the dextral sense proposed for the so-called "Rodeo Riedel", herein called the Bajada Fault. Although we do recognize the presence of a basement-controlled fault system, we partly disagree with the pure dextral slip sense. We observe that this fault is linked to the sinistral and en-echelon Carrizal fault system to the north, which propagates into the Progreso basin (Fig. 1). Our structural seismic mapping across the Progreso basin shows the prolongation of two main faults, herein called the "Bajada fault" to the south and the "Las Cañas fault" to the north (Fig. 1-B). The faults to the northeast show a clear en-echelon pattern, sealed by a regional late Eocene (?) unconformity (Fig. 3). This major late Eocene event is not depicted by Alemán et al., [2021] on their interpretation of inline 1550, which shows through going faults only. An interpretation that differs from Aizprua et al., [2019] on the same inline, which shows a soft link between both fault systems. Contrary to the detachment level ill-disposed inferred interpretation by Alemán et al., [2021]. We do agree with the basement involved deformation (middle to late Miocene) and the vertical linkage to pre-existing Eocene structures (Fig. 3-A). The reactivation of pre-existing structures is marked by the offset of the major unconformity mentioned above (Fig. 3-A). Based on our interpretation a major phase of transtension occurred during the middle to late Eocene, followed by a major unconformity in the region (late Eocene) (Fig. 3), and the re-orientation of the trench-parallel deformation from $\sim$ NW-SE (Eocene) to N-S (middle Miocene), the latest one most likely link to the tectonic escape of the Northern Andes in agreement with the work from Alvarado et al., [2016].

South of the Bajada fault, the fault system is associated with a clear $\mathrm{N}-\mathrm{S}$ extensional direction, which bends towards the SSE into an E-W extension direction (Fig. 3). This apparent change of the local stress field seems to be controlled by the intersection of two large-scale strike-slip fault systems at the southern sector of the Progreso Basin. The first one is associated with the interplay between the SEH and the Piñon Block (acting as a backstop), and the second one is related to the CCPP fault system. The latter generating a possible tectonic extrusion at the southernmost segment of the Progreso Basin. Thus, the Progreso Basin can be considered as a complex Neutral-Accretionary forearc basin (a type of transtensional basin) with the widening of its southern segment due to a lateral tectonic extrusion along the CCPP. This is a novel model, which takes into account all the surrounding tectonic elements and does not necessarily require a counterclockwise rotation as proposed by Alemán et al., [2021].

A negative flower structure might be associated with the "Bajada 

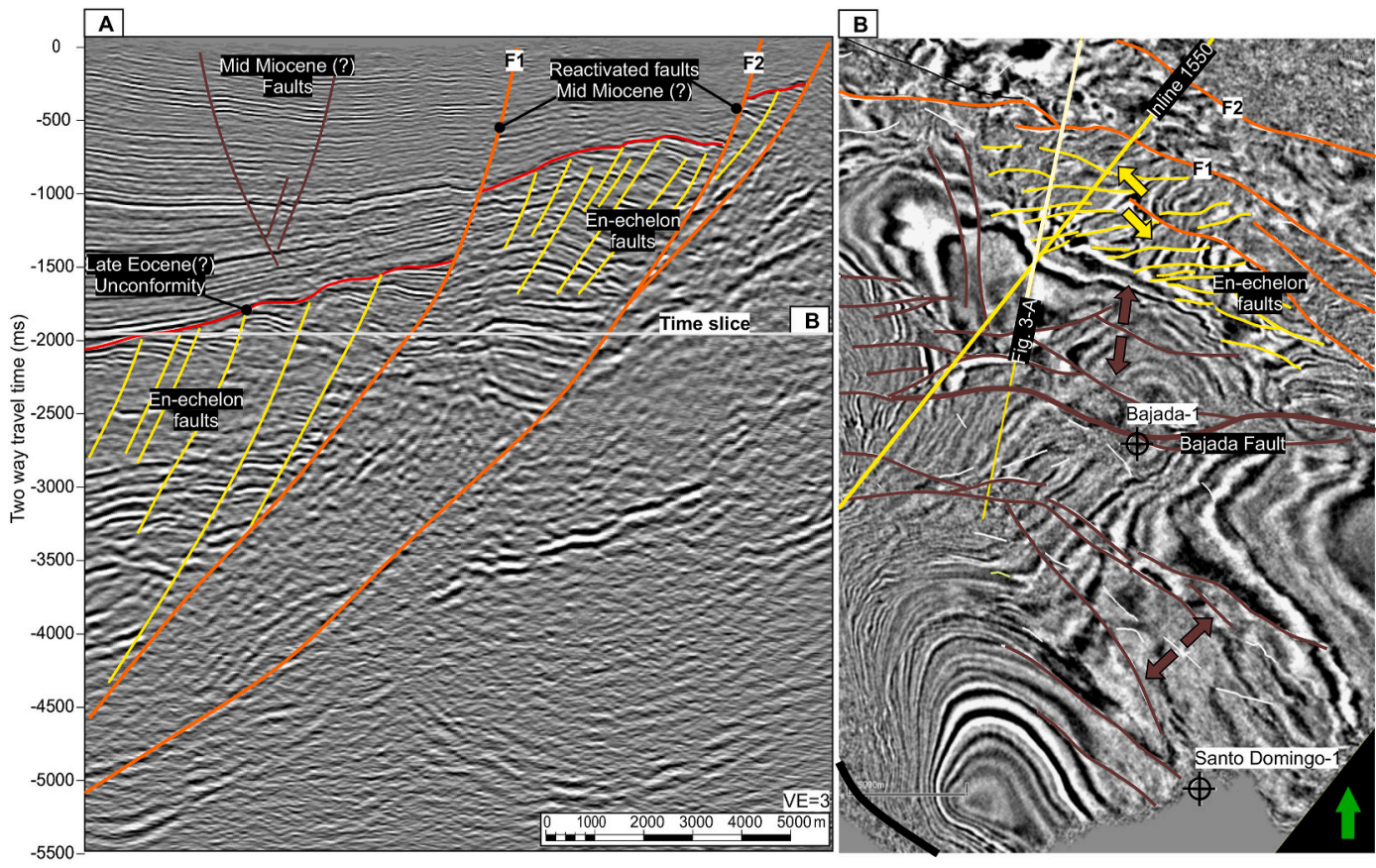

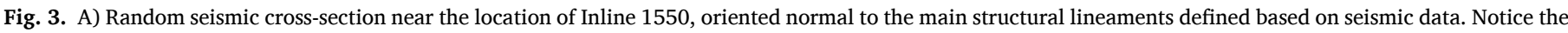

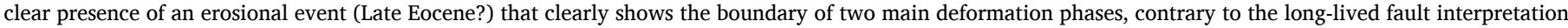

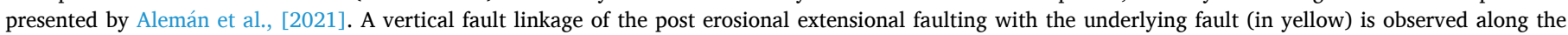

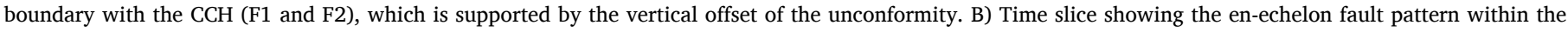

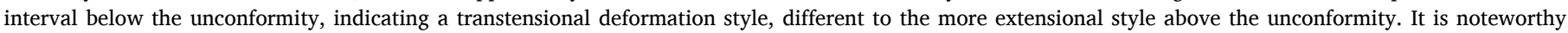

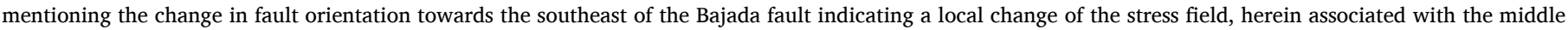
Miocene tectonic escape along the CCPP [Alvarado et al., 2016].

fault" by a dextral-strike slip movement, as seems to be the proposed interpretation by Alemán et al., [2021], however, it does not seem to be supported by the vertical derivative of the gravity anomaly and the integration of the different observations. For instance, the Bajada fault (Rodeo Riedel according to Alemán et al., [2021]) makes a clear bend to the north (Fig. 2-B), which under a dextral strike-slip sense movement should present a larger displacement near its bend. However, the maximum displacement is observed farther to the east. This complex fault zone is most likely associated to a lateral tectonic extrusion along the CCPP fault system, evidenced by the vertical derivative of the gravity anomaly (Fig. 1).

One additional point that we would like to reinforce through this comment, which has been a point of criticism from Alemán et al., [2021], is regarding the interpretation of inline 1550 across the Progreso Basin. The contrasting interpretations of inline 1550 might be partly valid around the Carrizal Fault System, and certainly, the point raised by Alemán et al., [2021] may modify some details of our interpretation near such faults. However, the main purpose of this seismic profile and the overall work in Aizprua et al., [2019] and Witt et al., [2019b], was to define the relationships between the main tectonic elements in the region. And, how these underlying elements, inherited from a Late Cretaceous oceanic plateau collision, might have controlled the development of the Cenozoic basin, rather than discussing in detail the development of the Progreso Basin.

\subsection{Chronological and petrographical data}

Another issue throughout the article is when referring to the Zapotal formation, Alemán et al., [2021] do not cite the source of the U-Pb detrital zircon ages. To mention some examples, we found the following: “... toward the top $\mathrm{U} / \mathrm{Pb}$ detrital zircon from an ashfall tuff unit interbedded with conglomeratic sandstones reported 14.3 Ma suggesting an important diachronous deposition"; or a bit further "Detrital zircons ages (32.5 Ma to 14.3 Ma) for this section indicate broader age than reported by Witt et al., [2019b]". Moreover, the youngest age (ca. 14 Ma) shown in figure $S 3$, which claim to compile 222 zircon grains dating from 5 ashfall tuffs from the Zapotal Formation, lack to indicate the source(s) for these analyses, like who measured these ages? Furthermore, key information is lacking in their analyses, for instance: 1) What type of ages are reported $(206 \mathrm{~Pb} / 238 \mathrm{U}$ ages? 207Pb/206 $\mathrm{Pb}$ ages? Something else?); 2) Were these rare (apparently less than 5) 14 Ma old analyses concordant? If so, how many grains were yielding the same age within error? Detrital zircon geochronology requires to be very rigorous when interpreting the dataset (see for example Gehrels [2014]Gehrels [2014]). Failing to do so can result in a wrong interpretation of the data and therefore produce false and/or misleading conclusions. Also, it is far from clear if the K/Ar age of about 19.5 Ma proposed in the same section refers to the Zapotal Formation and if it comes from the Alemán et al., [2021] study or it was obtained from literature records.

We strongly disagree with Alemán et al., [2021] who claim that "our random samples" did not confirm the age of the Subibaja Formation. Our sampling strategy was based on a regional recognition of key mapped outcrops across the entire study zone. Sample locations have been shown in tables and figures. Thus, it is surprising to see our sampling work systematically catalogued as "random" by Alemán et al., [2021] when these authors do not even provide the location of their analyzed samples, nor in the main body of the article or the supplementary sections. Finally, the subsidence curves proposed by Alemán et al., [2021] are, as their $\mathrm{U}-\mathrm{Pb}$ chronological constraints, largely vague in terms of the methodology. The name and location of the wells used in building the curves, the lithology, compaction parameters, among others, have not been considered or discussed in their publication.

\section{Summary}

The model proposed by Alemán et al., [2021] appears as a 
reasonable geometric-based solution, however, as we have discussed throughout this comment there are several aspects, in terms of methodology and data integration, that cast reasonable doubts on their model. In our opinion, the different tectonic processes presented by Alemán et al., [2021], which form the basis for their regional tectonic framework controlling the development of the Progreso Basin, require further details or evidence. Among those details we would like to have seen constraints on 1) the late Paleocene arc-plateau collision event ("Cayo arc" and Piñon Block), leading to the development of a NW-SE foredeep Paleocene-Eocene basin; and 2) structural and paleomagnetic constraints that support the proposal of a $\sim 30^{\circ}$ counterclockwise rotation of the Chongón/Colonche orocline. Moreover, it is expected that the same authors provide evidence of kinematic indicators of both the counterclockwise rotation and the coeval development of a Riedel system, which is able to prolong across the Progreso Basin and the SEH $(\sim 150 \mathrm{~km})$.

We do agree with Alemán et al., [2021] that our interpretations differed substantially from each other. Contrary to their model, we consider the presence of the different remnants that may have resulted from the Late Cretaceous collision and accretion event and the subsequent strain partitioning across the region. In addition to the data constraints, at different scales of observations, we have incorporated further advances on the understanding of the forearc region subject to the accretion of oceanic plateaus. In this regard, numerical models [Malatesta et al., 2013; Vogt and Gerya, 2014; Betts et al., 2015; Malatesta et al., 2016; Tao et al., 2020] together with analogues [e.g. Santra et al., 2013], show that the indentation of allochthonous terranes imposes a local deformation near its boundary accompanied by trench retreat and the development of a localized accretionary wedge near the presence of a natural boundary (in the current case study this boundary if form by the ATM and terranes extending farther W-SW). This accretionary process might have led to the development of a triple plate junction [Kennan and Pindell, 2009; Spikings et al., 2015; Aizprua et al., 2019], hosting the subsequent deposits from the Azúcar Fm. However, it is somehow uncertain whether the SEH developed 1) onto a remnant of an accretionary-type subduction system of Maastrichtian age (Santa Elena Fm.), as proposed by Aizprua et al., [2019], or 2) the SEH constitutes a singularity developed at a triple plate junction [see Fig. 12 in Kimura et al., 2014; Aizprua, 2021]. In both scenarios, the flexural bulge along NW Peru hosting the deposition of the Azúcar Fm. Seems to have been controlled by the collision and plate instability period, contrary to the Late Paleocene short-lived arc collision proposed by Alemán et al., [2021].

The resulting configuration in the southernmost Northern Andes resulted in the presence of a significantly stronger forearc sliver (Pinon Block acting as a backstop) than the trenchward remnant of an accretionary wedge (e.g Santa Elena and Azúcar Formations). Furthermore, we must consider the southern suture, which acted as a transform boundary. Thus, based on the deformation observed across the Progreso Basin and SEH, we interpret the Progreso Basin as a particular type of a neutral-accretionary forearc basin (based on the forearc basin classification by [Noda, 2016]), controlled by the complex interplay of oblique subduction, rise of an outer forearc high, and tectonic escape. The latter controlling the southern widening of the basin at least since the middle Miocene.

\section{Credit author statement}

Marc Poujol: Methodology, Writing - review \& editing. Diego Barba: Writing - review \& editing. Cesar Witt: Conceptualization, Supervision, Writing - review \& editing. Jean-Yves Reynaud: Writing - review \& editing. Carlos Aizprua: Conceptualization, Methodology, Formal analysis, Writing - original draft, Visualization, Software, Data curation

\section{Declaration of competing interest}

The authors declare that they have no known competing financial interests or personal relationships that could have appeared to influence the work reported in this paper.

\section{Acknowledgements}

The authors wish to thank editor-in-chief Taylor Schildgen from Tectonics and reviewer Adrian Pfiffner for their suggestions to improve the quality of an unpublished manuscript intended to Reply to a comment (unpublished) from Alemán et al. to Aizprua et al., [2019]. We are also thankful to Editor-in-Chief Dr. Andrés Folguera for reviewing the final version of the manuscript and for incentivizing the scientific discussion. Most of the data used for this study is accessible at the NTNU Open Research data repository (https://doi.org/10.18710/BYZIZX).

\section{References}

Aguilar, R.V., Aleman, A.M., Ordoñez, M.B.R., Montenegro, G., Noya, J.V., Ortega, R., 2009. Evolución Tectonoestratigráfica y Sistema Petrolífero de la Cuenca Progreso en Ecuador y Perú [PAPER IN Spanish] Tectonostratigraphic Evolution and Petroleum System of Basin Progreso in Ecuador and Peru.

Aizprua, C., 2021. Forearc Crustal Structure and Controlling Factors on Basin Formation across the Southernmost Northern Andes, Doctoral Thesis Thesis. Norwegian University of Science and Technology (NTNU) url: https://hdl.handle.net/11250/ 2723320.

Aizprua, C., Witt, C., Johansen, S.E., Barba, D., 2019. Cenozoic stages of forearc evolution following the accretion of a sliver from the late cretaceous-caribbean large igneous province: SW Ecuador-NW Peru. Tectonics 38 (4), 1441-1465. https://doi. org/10.1029/2018TC005235.

Aizprua, C., Witt, C., Brönner, M., Johansen, S.E., Barba, D., Hernandez, M.J., 2020 Forearc crustal structure of Ecuador revealed by gravity and aeromagnetic anomalies and their geodynamic implications. Lithosphere 2020 (1), 1-23. https://doi.org/ 10.2113/2020/2810692.

Alemán, A.M., Palencia, A.A., Lezama, E.E., Montenegro, G., 2021. The Chongón Colonche orocline transrotational bending and the coeval opening of the Progreso basin in southwestern Ecuador. J. S. Am. Earth Sci. 111, 103480. https://doi.org/ 10.1016/j.jsames. 2021.103480.

Alvarado, A., Audin, L., Nocquet, J.M., Jaillard, E., Mothes, P., Jarrin, P., Segovia, M., Rolandone, F., Cisneros, D., 2016. Partitioning of oblique convergence in the Northern Andes subduction zone: migration history and the present-day boundary of the North Andean Sliver in Ecuador. Tectonics 35 (5), 1048-1065. https://doi.org/ 10.1002/2016TC004117.

Andjić, G., Baumgartner-Mora, C., Baumgartner, P.O., Petrizzo, Maria R., 2018. Tectonostratigraphic response of the Sandino Forearc Basin (N-Costa Rica and W-Nicaragua) to episodes of rough crust and oblique subduction. The Depositional Record 4 (1), 90-132. https://doi.org/10.1002/dep2.40.

Barbosa-Espitia, Á.A., Kamenov, G.D., Foster, D.A., Restrepo-Moreno, S.A., PardoTrujillo, A., 2019. Contemporaneous Paleogene arc-magmatism within continental and accreted oceanic arc complexes in the northwestern Andes and Panama. Lithos 348-349, 105185. https://doi.org/10.1016/j.lithos.2019.105185.

Bayona, G., Cardona, A., Jaramillo, C., Mora, A., Montes, C., Valencia, V., Ayala, C., Montenegro, O., Ibañez-Mejia, M., 2012. Early Paleogene magmatism in the northern Andes: insights on the effects of oceanic plateau-continent convergence. Earth Planet Sci. Lett. 331-332, 97-111. https://doi.org/10.1016/j. epsl.2012.03.015.

Beck Jr., M.E., 1980. Paleomagnetic record of plate-margin tectonic processes along the western edge of North America. J. Geophys. Res. Solid Earth 85 (B12), 7115-7131. https://doi.org/10.1029/JB085iB12p07115.

Benitez, S., 1995. Évolution géodynamique de la province côtière sud-équatorienne au Crétacé supérieur-Tertiaire (Université Joseph-Fourier - Grenoble I).

Betts, P.G., Moresi, L., Miller, M.S., Willis, D., 2015. Geodynamics of oceanic plateau and plume head accretion and their role in Phanerozoic orogenic systems of China. Geosci. Front. 6 (1), 49-59. https://doi.org/10.1016/j.gsf.2014.07.002.

Boschman, L.M., van Hinsbergen, D.J.J., Torsvik, T.H., Spakman, W., Pindell, J.L., 2014. Kinematic reconstruction of the caribbean region since the early jurassic. Earth Sci. Rev. 138, 102-136. https://doi.org/10.1016/j.earscirev.2014.08.007.

Braz, C., Seton, M., Flament, N., Müller, R.D., 2018. Geodynamic reconstruction of an accreted Cretaceous back-arc basin in the Northern Andes. J. Geodyn. 121, 115-132. https://doi.org/10.1016/j.jog.2018.09.008.

Dewey, J.F., Lamb, S.H., 1992. Active tectonics of the Andes. Tectonophysics 205 (1), 79-95. https://doi.org/10.1016/0040-1951(92)90419-7.

Egüez, A., 1986. Evolution Cenozoique de la Cordillere Occidentale septentrionale d'Equateur $\left(0^{\circ} 15^{\prime} \mathrm{S}-01^{\circ} 10^{\prime} \mathrm{S}\right)$, les mineralisations associetees, vol. 116. Doc Thesis, UPMC, Paris.

Egüiez, A., Gaona, M., Albán, A., 2017. Mapa Geológico de la República del Ecuador, Escala 1: 1 000.000. Ministerio de Minería y Instituto Nacional de Investigación Geológico Minero Metalúrgico, Quito (in Spanish). 
Espurt, N., Brusset, S., Baby, P., Henry, P., Vega, M., Calderon, Y., Ramirez, L., Saillard, M., 2018. Deciphering the Late Cretaceous-Cenozoic structural evolution of the North Peruvian forearc system. Tectonics 251-282. https://doi.org/10.1002/ 2017TC004536.

Gehrels, G., 2014. Detrital zircon U-Pb geochronology applied to tectonics. Annu. Rev. Earth Planet Sci. 42 (1), 127-149. https://doi.org/10.1146/annurev-earth-050212 124012.

George, S.W.M., Horton, B.K., Vallejo, C., Jackson, L.J., Gutierrez, E.G., 2021. Did accretion of the Caribbean oceanic plateau drive rapid crustal thickening in the northern Andes? Geology. https://doi.org/10.1130/G48509.1.

Godfrey, N.J., Beaudoin, B.C., Klemperer, S.L., 1997. Ophiolitic basement to the Great Valley forearc basin, California, from seismic and gravity data: implications for crustal growth at the North American continental margin. Geol. Soc. Am. Bull. 109 (12), 1536-1562

Gutscher, M.A., Olivet, J.L., Aslanian, D., Eissen, J.P., Maury, R., 1999. The "lost inca plateau": cause of flat subduction beneath Peru? Earth Planet Sci. Lett. 171 (3), 335-341. https://doi.org/10.1016/S0012-821X(99)00153-3.

Hernandez-Moreno, C., Speranza, F., Di Chiara, A., 2016. Paleomagnetic rotation pattern of the southern Chile fore-arc sliver $\left(38^{\circ} \mathrm{S}-42^{\circ} \mathrm{S}\right)$ : a new tool to evaluate plate locking along subduction zones. J. Geophys. Res. Solid Earth 121 (2), 469-490. https://doi. org/10.1002/2015JB012382.

Hessler, A.M., Fildani, A., 2015. Andean forearc dynamics, as recorded by detrital zircon from the Eocene talara basin, northwest Peru. J. Sediment. Res. 85 (6), 646-659. https://doi.org/10.2110/jsr.2015.45

Hughes, R.A., Pilatasig, L.F., 2002. Cretaceous and tertiary terrane accretion in the cordillera Occidental of the Andes of Ecuador. Tectonophysics 345 (1-4), 29-48. https://doi.org/10.1016/S0040-1951(01)00205-0.

Jaillard, E., Benitez, S., Mascle, G.H., 1997. Palaeogene deformations of the forearc zone of south Ecuador in relation to the geodynamic evolution. B Soc Geol Fr 168 (4), 403-403.

Jaillard, E., Lapierre, H., Ordonez, M., Toro Alava, J., Amortegui, A., Vanmelle, J., 2009. Accreted Oceanic Terranes in Ecuador; Southern Edge of the Caribbean Plate?, vol. 328. Geological Society Special Publications, pp. 469-485. https://doi.org/10.1144/ SP328.19.

Jaillard, E., Ordoñez, M., Benitez, S., Berrones, G., Jiménez, N., Montenegro, G., Zambrano, I., 1995. Basin development in an accretionary, oceanic-floored fore-arc setting: southern coastal Ecuador during late Cretaceous-late Eocene time. https:// doi.org/10.1306/M62593C32.

Jaramillo, J.S., Cardona, A., León, S., Valencia, V., Vinasco, C., 2017. Geochemistry and geochronology from Cretaceous magmatic and sedimentary rocks at $6^{\circ} 35^{\prime} \mathrm{N}$ western flank of the Central cordillera (Colombian Andes): magmatic record of arc growth and collision. J. S. Am. Earth Sci. 76, 460-481. https://doi.org/10.1016/j. jsames.2017.04.012.

Kennan, L., Pindell, J.L., 2009. Dextral shear, terrane accretion and basin formation in the Northern Andes: best explained by interaction with a Pacific-derived Caribbean Plate? Geol Soc Spec Publ 328, 487-531. https://doi.org/10.1144/SP328.20.

Kerr, A.C., Aspden, J.A., Tarney, J., Pilatasig, L.F., 2002. The nature and provenance of accreted oceanic terranes in western Ecuador: geochemical and tectonic constraints. J Geol Soc London 159, 577-594. https://doi.org/10.1144/0016-764901-151.

Kimura, G., Hashimoto, Y., Kitamura, Y., Yamaguchi, A., Koge, H., 2014. Middle Miocene swift migration of the TTT triple junction and rapid crustal growth in southwest Japan: a review. Tectonics 33 (7), 1219-1238. https://doi.org/10.1002/ 2014TC003531.

Lebrat, M., Megard, F., Juteau, T., Calle, J., 1985. Pre-Orogenic volcanic assemblages and structure in the western cordillera of Ecuador between 1-degrees-40s and 2degrees-20s. Geol. Rundsch. 74 (2), 343-351. https://doi.org/10.1007/ BF01824901.

Luzieux, L., 2007. Origin and Late Cretaceous-Tertiary Evolution of the Ecuadorian Forearc.

Luzieux, L., Heller, F., Spikings, R., Vallejo, C.F., Winkler, W., 2006. Origin and Cretaceous tectonic history of the coastal Ecuadorian forearc between 1 degrees $\mathrm{N}$ and 3 degrees S: paleomagnetic, radiometric and fossil evidence. Earth Planet Sci. Lett. 249 (3-4), 400-414. https://doi.org/10.1016/j.epsl.2006.07.008.

Macías, K., 2018. Geoquímica de los Plutones de Pascuales y de Bajo Grande (Cantón Jipijapa): dataciones U-Pb en Zircones e implicaciones geodinámicas. Universidad de Guayaquil url: http://repositorio.ug.edu.ec/handle/redug/34182.

Malatesta, C., Gerya, T., Crispini, L., Federico, L., Capponi, G., 2013. Oblique subduction modelling indicates along-trench tectonic transport of sediments. Nat. Commun. 4 https://doi.org/10.1038/ncomms3456.

Malatesta, C., Gerya, T., Crispini, L., Federico, L., Capponi, G., 2016. Interplate deformation at early-stage oblique subduction: 3-D thermomechanical numerical modeling. Tectonics 35 (7), 1610-1625.

Maloney, K.T., Clarke, G.L., Klepeis, K.A., Quevedo, L., 2013. The Late Jurassic to present evolution of the Andean margin: drivers and the geological record. Tectonics 32 (5), 1049-1065. https://doi.org/10.1002/tect.20067.

Mamberti, M., Lapierre, H., Bosch, D., Jaillard, E., Ethien, R., Hernandez, J., Polve, M., 2003. Accreted fragments of the late cretaceous caribbean- Colombian plateau in Ecuador. Lithos 66 (3-4), 173-199. https://doi.org/10.1016/S0024-4937(02) 00218-9.

Mankhemthong, N., Doser, D.I., Pavlis, T.L., 2013. Interpretation of gravity and magnetic data and development of two-dimensional cross-sectional models for the Border Ranges fault system, south-central Alaska. Geosphere 9 (2), 242-259. https://doi. org/10.1130/GES00833.1.

McGeary, S., Nur, A., Ben-Avraham, Z., 1985. Spatial gaps in arc volcanism: the effect of collision or subduction of oceanic plateaus. Tectonophysics 119 (1), 195-221. https://doi.org/10.1016/0040-1951(85)90039-3.
Mitouard, P., Kissel, C., Laj, C., 1990. Postoligocene rotations in southern Ecuador and northern Peru and the formation of the huancabamba deflection in the andean cordillera. Earth Planet Sci. Lett. 98 (3-4), 329-339. https://doi.org/10.1016/0012821X(90)90035-V.

Moreno, A., 1983. Estratigrafía detallada del Grupo Azúcar en los acantilados de Playas. Escuela Superior Politécnica del Litoral, 182.

Noble, S.R., Aspden, J.A., Jemielita, R., 1997. Northern Andean crustal evolution: new UPb geochronological constraints from Ecuador. Geol. Soc. Am. Bull. 109 (7), 789-798.

Noda, A., 2016. Forearc basins: types, geometries, and relationships to subduction zone dynamics. Geol. Soc. Am. Bull. 128 (5-6), 879-895. https://doi.org/10.1130/ B31345.1.

Ordoñez, M., Jiménez, N., Suárez, J., 2006. Micropaleontología ecuatoriana. datos bioestratigráficos y paleoecológicos de las cuencas: : Graben de Jambelí, Progreso, Manabí, Esmeraldas y Oriente; del levantamiento de la península de Santa Elena, y de las cordilleras Chongón Colonche, costera y Occidental. Petroproducción y Centro de Investigaciones Geológicas de Guayaquil, Quito, Ecuador.

Palencia, A., Aleman, A., Aguilar, R., Barba, D.P., Lezama, E., Rivadeneira, M., Ortega, R. A., 2013. Tectono-stratigraphic Development of the Progreso Pull-Apart Basin in Southwestern Ecuador. American Association of Petroleum Geologists International Conference Abstracts, 2013.

Pepper, M., Gehrels, G., Pullen, A., Ibanez-Mejia, M., Ward, K.M., Kapp, P., 2016. Magmatic history and crustal genesis of western South America: constraints from U$\mathrm{Pb}$ ages and $\mathrm{Hf}$ isotopes of detrital zircons in modern rivers. Geosphere 12 (5), 1532-1555. https://doi.org/10.1130/ges01315.1.

Ramos, V.A., Folguera, A., 2009. Andean flat-slab subduction through time. Geological Society, London, Special Publications 327 (1), 31-54. https://doi.org/10.1144/ sp327.3.

Reynaud, C., Jaillard, E., Lapierre, H., Mamberti, M., Mascle, G.H., 1999. Oceanic plateau and island arcs of southwestern Ecuador: their place in the geodynamic evolution of northwestern South America. Tectonophysics 307 (3-4), 235-254. https://doi.org/10.1016/S0040-1951(99)00099-2.

Richards, M., Bowman, M., Reading, H., 1998. Submarine-fan systems i: characterization and stratigraphic prediction. Mar. Petrol. Geol. 15 (7), 689-717. https://doi.org/ 10.1016/S0264-8172(98)00036-1.

Riel, N., Martelat, J.-E., Guillot, S., Jaillard, E., Monié, P., Yuquilema, J., Duclaux, G., Mercier, J., 2014. Fore arc tectonothermal evolution of the El Oro metamorphic province (Ecuador) during the Mesozoic. Tectonics 33 (10), 1989-2012. https://doi. org/10.1002/2014TC003618.

Ron, H., Freund, R., Garfunkel, Z., Nur, A., 1984. Block rotation by strike-slip faulting: structural and paleomagnetic evidence. J. Geophys. Res. Solid Earth 89 (B7), 6256-6270. https://doi.org/10.1029/JB089iB07p06256.

Roperch, P., Megard, F., Laj, C., Mourier, T., Clube, T.M., Noblet, C., 1987. Rotated oceanic blocks in western Ecuador. Geophys. Res. Lett. 14 (5), 558-561. https://doi. org/10.1029/GL014i005p00558.

Santra, M., Steel, R.J., Olariu, C., Sweet, M.L., 2013. Stages of sedimentary prism development on a convergent margin - Eocene tyee forearc basin, coast Range, Oregon, USA. Global Planet. Change 103, 207-231. https://doi.org/10.1016/j. gloplacha.2012.11.006.

Schutte, P., 2009. Geochronology, geochemistry, and isotopic composition ( $\mathrm{Sr}, \mathrm{Nd}, \mathrm{Pb})$ of Tertiary porphyry systems in Ecuador. url: https://nbn-resolving.org/urn:nbn:ch:uni ge-63675.

Schutte, P., Chiaradia, M., Beate, B., 2010. Geodynamic controls on Tertiary arc magmatism in Ecuador: constraints from U-Pb zircon geochronology of OligoceneMiocene intrusions and regional age distribution trends. Tectonophysics 489 (1-4), 159-176. https://doi.org/10.1016/j.tecto.2010.04.015.

Seyler, M., Witt, C., Omaña, B., Durand, C., Chiaradia, M., Villagomez, D., Poujol, M. 2021. Late Cretaceous felsic intrusions in oceanic plateau basalts in SW Ecuador: markers of subduction initiation? J. S. Am. Earth Sci. 110, 103348. https://doi.org/ 10.1016/j.jsames.2021.103348.

Shanmugam, G., Moiola, R.J., 1991. Types of submarine fan lobes: models and Implications1. AAPG Bull. 75 (1), 156-179. https://doi.org/10.1306/0c9b276d1710-11d7-8645000102c1865d.

Siravo, G., Speranza, F., Mulas, M., Costanzo-Alvarez, V., 2021. Significance of northern Andes terrane extrusion and genesis of the interandean valley: paleomagnetic evidence from the "Ecuadorian orocline". Tectonics 40 (7), e2020TC006684. https://doi.org/10.1029/2020TC006684.

Spikings, R., Cochrane, R., Villagomez, D., Van der Lelij, R., Vallejo, C., Winkler, W., Beate, B., 2015. The geological history of northwestern south America: from pangaea to the early collision of the caribbean large igneous province (290-75 Ma). Gondwana Res. 27 (1), 95-139. https://doi.org/10.1016/j.gr.2014.06.004.

Spikings, R.A., Winkler, W., Hughes, R.A., Handler, R., 2005. Thermochronology of allochthonous terranes in Ecuador: unravelling the accretionary and postaccretionary history of the Northern Andes. Tectonophysics 399 (1-4), 195-220. https://doi.org/10.1016/j.tecto.2004.12.023.

Tao, J., et al., 2020. Accretion of oceanic plateaus at continental margins: numerical modeling. Gondwana Res. 81, 390-402. https://doi.org/10.1016/j.gr.2019.11.015.

Teyssier, C., Tikoff, B., Markley, M., 1995. Oblique plate motion and continental tectonics. Geology 23 (5), 447-450. https://doi.org/10.1130/0091-7613(1995) 023\%3C0447:OPMACT\%3E2.3.CO;2.

Vallejo, C., 2007. Evolution of the Western Cordillera in the Andes of Ecuador (Late Cretaceous-Paleogene). Eidgenoessische Technische Hochschule Zuerich, Zurich, Switzerland, p. 213.

Vallejo, C., Winkler, W., Spikings, R.A., Luzieux, L., Heller, F., Bussy, F., 2009. Mode and Timing of Terrane Accretion in the Forearc of the Andes in Ecuador, vol. 204. 
Geological Society of America Memoirs, pp. 197-216. https://doi.org/10.1130/ 2009.1204(09.

Vallejo, C., Soria, F., Tornos, F., Naranjo, G., Rosero, B., Salazar, F., Cochrane, R., 2016 Geology of El Domo deposit in central Ecuador: a VMS formed on top of an accreted margin. Miner. Deposita 51 (3), 389-409. https://doi.org/10.1007/s00126-0150616-x.

Vallejo, C., Spikings, R.A., Horton, B.K., Luzieux, L., Romero, C., Winkler, W., Thomsen, T.B., 2019. Chapter 8 - late cretaceous to miocene stratigraphy and provenance of the coastal forearc and Western Cordillera of Ecuador: evidence for accretion of a single oceanic plateau fragment. In: Horton, B.K., Folguera, A. (Eds.) Andean Tectonics. Elsevier, pp. 209-236.

van Hunen, J., van den Berg, A.P., Vlaar, N.J., 2002. On the role of subducting oceanic plateaus in the development of shallow flat subduction. Tectonophysics 352 (3), 317-333. https://doi.org/10.1016/S0040-1951(02)00263-9.

Van Melle, J., Vilema, W., Faure-Brac, B., Ordonez, M., Lapierre, H., Jimenez, N., Jaillard, E., Garcia, M., 2008. Pre-collision evolution of the Pinon oceanic terrane of SW Ecuador: stratigraphy and geochemistry of the "Calentura Formation. B Soc Geol Fr 179 (5), 433-443. https://doi.org/10.2113/gssgfbull.179.5.433.

Vogt, K., Gerya, T.V., 2014. From oceanic plateaus to allochthonous terranes: numerica modelling. Gondwana Res. 25 (2), 494-508. https://doi.org/10.1016/j. gr.2012.11.002.

Walker, R.G., 1978. Deep-water sandstone facies and ancient submarine fans: models for exploration for stratigraphic Traps1. AAPG Bull. 62 (6), 932-966. https://doi.org/ 10.1306/c1ea4f77-16c9-11d7-8645000102c1865d.

Wallace, L.M., Beavan, J., McCaffrey, R., Darby, D., 2004. Subduction zone coupling and tectonic block rotations in the North Island, New Zealand. J. Geophys. Res. Solid Earth 109 (B12). https://doi.org/10.1029/2004JB003241.
Witt, C., Aizprua, C., Reynaud, J.Y., Amberg, C., Poujol, M., 2018. An U-Pb zircon chronology based correlation for forearc sediments through the Ecuadorian Peruvian border, paper presented at Réunion des Sciences de la Terre. Lille-France, pp. 22-26 October.

Witt, C., Poujol, M., Chiaradia, M., Villagomez, D., Seyler, M., 2019a. Evolution of the Northern Andes Cenozoic magmatic arc as recorded in the forearc detrital record. In: 8th International Symposium on Andean Geodynamics (ISAG) (Quito-Ecuador).

Witt, C., Bosch, D., Aizprua, C., Poujol, M., Chiaradia, M., 2021. Geodynamic controls at the southernmost Northern Andes magmatic arc: geochemical and geophysical evidence, paper presented at Réunion des. Sciences de la Terre, Lyon (France).

Witt, C., Rivadeneira, M., Poujol, M., Barba, D., Beida, D., Beseme, G., Montenegro, G., 2017. Tracking ancient magmatism and Cenozoic topographic growth within the Northern Andes forearc: constraints from detrital U-Pb zircon ages. Geol. Soc. Am. Bull. https://doi.org/10.1130/B31530.1.

Witt, C., Reynaud, J.Y., Barba, D., Poujol, M., Aizprua, C., Rivadeneira, M., Amberg, C., 2019b. From accretion to forearc basin initiation: the case of SW Ecuador, Northern Andes. Sediment. Geol. 379, 138-157. https://doi.org/10.1016/j. sedgeo.2018.11.009.

Woodcock, N.H., 1986. The role of strike-slip-fault systems at plate boundaries. Philos T R Soc A 317 (1539), 13-29. https://doi.org/10.1098/rsta.1986.0021.

Zapata-Villada, J.P., Cardona, A., Serna, S., Rodríguez, G., 2021. Late Cretaceous to Paleocene magmatic record of the transition between collision and subduction in the Western and Central Cordillera of northern Colombia. J. S. Am. Earth Sci. 103557 https://doi.org/10.1016/j.jsames.2021.103557. 